\title{
Interleukin Signaling Process
}

National Cancer Institute

\section{Source}

National Cancer Institute. Interleukin Signaling Process. NCI Thesaurus. Code C40588.

Any process which promotes expression of the interleukin proteins, their secretion, receptor binding or intracellular signaling, and promotes proliferation and differentiation among target populations, inflammation, chemotaxis, production of antibodies and modulation of further cytokine expression. This process is involved in regulating active populations of leukocytes and coordinating systemic responses to pathogenic infection. 